\title{
The power of social media storytelling in destination branding
}

\author{
Niels Frederik Lund ${ }^{a},{ }^{*} \&$ Scott A. Cohen ${ }^{b}$ \& Caroline Scarles ${ }^{b}$ \\ ${ }^{a}$ Bournemouth University, Faculty of Management, Department of Events and Leisure, Talbot \\ Campus, Fern Barrow, Poole, Dorset, BH12 5BB UK, e-mail: nlund@bournemouth.ac.uk \\ ${ }^{b}$ University of Surrey, Faculty of Arts and Social Sciences, School of Hospitality and Tourism \\ Management, Guildford GU2 7XH, UK, e-mail: s.cohen@surrey.ac.uk \\ ${ }^{\mathrm{c}}$ University of Surrey, Faculty of Arts and Social Sciences, School of Hospitality and Tourism \\ Management, Guildford GU2 7XH, UK, e-mail: c.scarles@surrey.ac.uk \\ *Corresponding author: Niels Frederik Lund nlund@bournemouth.ac.uk
}

\section{ABSTRACT}

A large part of the global population is now connected in online social networks in social media where they share experiences and stories and consequently influence each other's perceptions and buying behaviour. This poses a distinct challenge for destination management organisations, who must cope with a new reality where destination brands are increasingly the product of people's shared tourism experiences and storytelling in social networks, rather than marketing strategies. This article suggests a novel interpretation on how these online social networks function with regard to generating engagement and stimulating circulation of brand stories by offering a conceptual framework based on the sociological concepts of storytelling, performance, performativity, and mobility. These concepts are characterised as 'technologies of power', for their role in shaping the social mechanisms in social media. VisitDenmark, the DMO of Denmark, is used as a case to put the framework into practice. The case demonstrates how DMOs can use the framework to strengthen their social media branding, and five practical recommendations for how to do so are provided.

Keywords: Social media; Destination branding; DMOs; Storytelling; Technologies of power; Netnography. 


\section{Introduction}

Consumers are increasingly connecting in social media where the sharing of personal stories influences their behaviour, including where they go and what they purchase (Adams, 2012). As social media provide popular spaces for people to communicate and share content, they have also become an important source for prospective tourists to find information and search for prices, suppliers, availability and product features (Buhalis \& Foerste, 2015). Social media have therefore evolved into important channels for marketing (Kaplan \& Haenlein, 2010), with for instance approximately $60 \%$ of destination marketing organisations (DMOs) having dedicated budgets for social media related activities (Barnes, 2015). However, social media also elevates the role of consumers in the co-creation of brands and communications. Social media therefore pose a particular challenge for marketers, as they must deal with a new situation where brands are increasingly the product of people's conversations in social networks, rather than formal marketing strategies (Fournier \& Avery, 2011). The classic marketing model premised on control and predictability is no longer viable (Fisher \& Smith, 2011). The emergence of social media thus requires a fundamental rethink of marketing practises as brands are now co-created through informal conversations by authors largely outside marketers' control. While a brand may initially embody a manufactured commercialised story, consumers' storytelling of personal experiences and opinions becomes absorbed into the brand narrative, hence changing, diluting or disintegrating its identity. Social media are therefore facilitating a democratisation of media production and a power shift towards consumers who can now produce content and publish via communication channels where marketers are not invited (Peters, Chen, Kaplan, Ognibeni \& Pauwels, 2013; Kietzman, Hermkens, McCarthy \& Silvestre, 2011; DesAutels, 2011). As Berthon, Pitt, Plangger and Shapiro (2012, p. 289) suggest, the effects of social media "are sociological and little short of revolutionary in their implications for business".

This article advances on recent perspectives on social media as spaces of storytelling, which focus on consumer generated brand stories, co-creation, open-source branding and improvised performances (Gensler, Völckner, Liu-Thompkins, \& Wiertz, 2013; Singh \& Sonnenburg, 2012; Fournier \& Avery, 2011). It offers a conceptual framework that draws on particular sociological concepts to illustrate how a combination of individuals' performative acts, mobilities and storytelling competencies enable stories to spread and influence 
narratives, discourses and perceptions. Specifically, it is argued that the concepts of storytelling, mobilities, performance and performativity can be conceptualised as 'technologies of power', which are techniques used in the practical operation of power that can be utilised by individuals and groups in social media to exert influence on others (Foucault, 1977).

The conceptual framework is applied in a netnographic case study of Facebook posts by VisitDenmark, the Danish national DMO. This brief practical example from VisitDenmark's social media branding practices is provided to illustrate the power of the conceptual framework. The case demonstrates how DMOs can use the framework to strengthen their social media branding, and the paper concludes with practical recommendations for how to do so.

\section{Social media and Marketing Destinations}

DMOs responsible for marketing tourism destinations offer an ideal case for analysing the potential of the conceptual framework developed in this paper. Tourism is an integrated part of many people's lives, which is observable on social media where the third most popular topic on Facebook after music and television is holidays and travel experiences (Bertino, 2014). Traveling presents countless photo opportunities and experiences in extended phases where social media offers a suitable outlet for sharing these experiences with social networks. DMOs can engage with these social media users and their stories. Particularly DMOs can connect with Generation $\mathrm{Y}$ as technology and online social networking is integrated into nearly every aspect of their lives and is a central part of their leisure experiences (Leask, Fyall \& Barron, 2014). As not all prospective tourists are active social media users, the conceptual framework and its implications is therefore applicable to people who are social media users.

The tourism sector is a place with a high visibility of consumption, which make the brands of destinations more susceptible to social media conversations and stories. Research shows that $93 \%$ of travellers are influenced by reviews in their travel planning and $80 \%$ of people about to make a travel purchase will ask members of their social network for a recommendation first (Digital Tourism Think Tank, 2013). Online stories have the potential to influence substantial numbers of future visitors who go online in search of first-person 
unbiased accounts (Martin, Woodside \& Dehuang, 2007). Tourism products are sold in advance of consumption, and decision-making in purchases relies significantly on positive stories and electric word-of-mouth (eWOM) via sites such as TripAdvisor and Facebook. If consumers do not trust in the destination or tourism company, they are unlikely to take the risk of buying. The tourism sector is thus sensitive to the countless mediated tourism experiences in social media.

To successfully brand destinations, DMOs have to mine social media data to capture and interpret its visitors' positive and negative images (Kladou \& Mavragani, 2015); DMOs must examine their visitors' stories to understand how they enact the myths facilitated by the destinations (Woodside, Cruickshank \& Dehuang, 2007). Social media is a key focus area for DMOs' branding strategies (Hays, Page \& Buhalis, 2013). The conceptual framework that follows gives DMOs new insights into the complex social mechanisms of social media and it provides answers as to why some stories become popular and widely shared while others fail to gain traction. DMOs can utilise the framework to analyse the social media behaviour of users and use the technologies of power discussed below to circulate their preferred version of the brand effectively among social media users. It thus facilitates a practical basis for DMOs to improve branding practices and strategies.

\section{A Sociological Approach to Social Media Marketing}

Even though companies are mainly interested in social media to find ways to market their products, marketing is a moderately small and peripheral part of the social media consumer culture and consumers pay little attention to it (Kohli, Suri \& Kapoor, 2015). Social media are primarily communication systems that allow their social actors to communicate (Peters et al., 2013), often using relatively informal and organic narratives that exist separate to formal spaces of marketing strategies. Social media are a new tool for speaking with friends, family and organisations, and as such should not be regarded as separate from the offline world. They can be viewed as more than just an evolution of technology. Rather, social media represent a social revolution (Tiago \& Verissimo, 2014), as offline and online worlds become intertwined, facilitated by mobile technologies such as tablets and smartphones (Adams, 2012). 
As social media generate spaces for socialising and connecting with friends and relatives, thereby resembling social networks in the offline world, it is surprising how few articles within the field of social media marketing have turned to sociology to increase understanding of their social processes. Some exceptions include, for instance, Wang, Yu and Wei (2012) who apply consumer socialisation theory in social media branding in order to understand how peer communication through social media impacts consumer decision making and thus marketing strategies. Wang et al. (2012) identify socialisation agents (peers) within social media, who transmit norms, values, attitudes, motivations, and behaviours to others via a social learning process. Similarly, Labrecque (2014) applies parasocial interaction theory (PSI) in order to design successful social media strategies. PSI is described as an illusionary experience that makes consumers interact with media representations of presenters, celebrities or characters as if they are present and engaged in a reciprocal relationship (ibid). While both Wang et al. (2012) and Labrecque (2014) step into the sphere of sociology, consumer socialisation theory and PSI are still theories that are developed for marketing purposes. One notable exception is the conceptual framework developed by Peters et al. (2013), who draw on social network theory and see social media as a social structure made up of a set of social actors within communication systems that enable them to communicate along dyadic ties. On that basis, a brand can be seen as essentially a node, or an actor, just like any other in a network with no special authority to impose commercial messages on others (Peters et al., 2013).

The lack of sociological approaches in social media marketing is problematic as social media are a sphere for social networking and conversations. If DMOs are to better understand the social mechanisms of social media, there is a need to gain an understanding of how people act, socialise and influence each other within social media using a sociological approach. The conceptual framework developed in this article helps to facilitate this. However, it is first necessary to consider how social media has given a voice to its users for sharing stories and co-creating brands.

\section{Democratisation and the Co-created Brand}

The emergence of social media facilitates a democratisation of media production, which shifts the locus of market power from firms to consumers as they can now produce and publish content (Berthon et al., 2012; Kietzman et al., 2011; Tiago and Verissimo, 2014). This 
is egalitarian in nature as consumers and social media managers are repositioned as equal actors in the network (Peters et al., 2013). In contrast to the traditional integrated marketing communications paradigm, where a high degree of control was present, social media-based conversations are now occurring outside managers' direct influence (Mangold \& Faulds, 2009). Once brands are out in the market, consumers now have growing power to renegotiate, alter and fragment the brand narratives according to personal experiences and opinions (Kohli et al., 2015). DMOs therefore have to cope with a new reality where traditional media no longer control the value and importance allocation within the domain of traveling (Lo, McKercher, Lo, Cheung, Law, 2011). As Peters et al. (2013) observe, companies do not have panoptic authority to impose advertisements anymore as this conflicts with the dialogic nature of social media. This new situation make brands more transparent and marketing campaigns more susceptible to parody and criticism (Fournier \& Avery, 2011). Users are likely to shut out brands that push too much and are a nuisance (Kaplan, 2012; Kietzman et al., 2011). Consequently, marketers who used to seek people to consume their products, now seek people to produce the value they want to leverage (Berthon et al., 2012). Co-creation entails strategically passing off control of the brand and letting it go (Fisher \& Smith, 2011) and engage in dialogical relationships with consumers; recognising and embracing the role of consumers in the co-construction of brand identity.

According to Labrecque, vor dem Esche, Mathwick, Novak and Hofacker (2013), there are four sources of consumer power: two of these are individual-based power sources (demand and information-based power); while the others are network-based power sources (network- and crowd-based power). This paper builds on two of these four sources. Firstly, information-based power where users can create user-generated-content, which enables empowerment by providing an outlet for self-expression, extending individual reach and elevating the potential for personal opinions to influence markets (Labrecque et al., 2013). Secondly, network-based power where users can build personal reputation and influence social networks. These two types of power play a critical role in the co-creation of brands as users can produce individual content about brands while also modifying and commenting on brand narratives created by marketers.

The democratisation of information production means that the construction of brands within social media can be interpreted as a collective, active co-creational process involving multiple brand authors who all contribute their stories (Gensler et al., 2013). Marketers and 
consumers are both active agents within the production, sharing and consumption of knowledge. Brand narratives flow through social networks, from one user to the next, splintering into various sub-stories and versions depending on the interests and personalities of the users. Fournier and Avery (2011) call this co-created process 'open source branding' where brands are embedded in cultural conversations. Brands emerge as products of co-constructed improvised performances where social media users choose to play different roles that vary from narrator to listener, director to spectator (Singh \& Sonnenburg, 2012). The co-creation of brands therefore makes the image and lifestyle of consumers more visible and active in the construction of brand identity (Gensler et al., 2013). Thus, brands emerge as an amalgam of multiple identities, driven by a fusion of organisational and consumer characteristics and requirements. In this new environment, it is especially important for DMOs to create connections and alliances with tourists as they have an immense impact on the destination brand via their shared experiences.

\section{Branding and destination management organisations}

DMOs are stewards of the destination reputation by facilitating brand management in cooperation with the whole tourism system (Morgan, Pritchard \& Pride, 2011). However, the reality for DMOs is that the destination image is derived from a host of sources, of which tourism marketing is but one (ibid). It can therefore be difficult to develop an umbrella brand as DMOs struggle to control the messages coming from the local community, the tourism industry and politicians (Pike, 2004). DMOs also lack control of their product and they can seldom be involved in pricing and quality unless they are coordinating a campaign with some tourism sector players (Morrison, 2013). In addition, tourists are co-creating their experiences with locals and marketers and contribute to forming the destination's identity as they share these personal experiences on social media. Tourists thus have a stake in the destination's brand as well. Due to these factors, the destination image may bear little resemblance to the intended brand identity (Pike, 2004).

Destination branding therefore has some unique characteristics as opposed to branding more generally, where companies market products and services which they fully control in terms of production, distribution and marketing. However, as stewards of the brand, DMOs have a commitment towards constructing or at least influencing brand narratives through 
their social media activities. As Morgan and Pritchard (2004) advocate, the brand winners are the destinations that are rich in emotional meaning and hold great conversational value. Social media storytelling provides a conduit for DMOs to generate emotional responses and enter into a dialogue with tourists.

Due to the co-creative characteristic of social media, DMOs should not try to control or manipulate consumer response and communication. As brand managers, DMOs should utilise these co-creating consumers as their positive brand stories can be an invaluable asset (Gensler et al., 2013). This is particularly the case for consumers who hold greater influence than others. Brands must be flexible as they are identity resources used as a basis for creating meaningful consumer interactions and experiences (Fisher and Smith, 2011). The stories of brands developed through social media can therefore be integrated into marketers' communication mix where the inclusion of personal stories and lived experiences can create an emotional connection with the consumer. Marketing can no longer solely be about capturing attention via reach; instead, marketers must focus on both capturing and continuing attention via engagement through dialogue (Hanna, Rohm \& Crittenden, 2011). They can provide consumers with the necessary tools and the branding 'raw material' by which to actively encourage them to provide brand stories (Gensler et al., 2013). It is important that the raw material is easily incorporated into the content that users utilise for self-promotion and personal marketing as it must add value to their communal newsfeed (Anderson, Hamilton \& Tonner, 2016). Hence, by creating resonant culturallydriven conversations, social rituals and cultural icons, marketers can inspire consumer conversations about the brand (Fournier \& Avery, 2011). Thus, they can act as curators of social media content and provide a space where conversations can occur and entice consumers to participate through relevant and valuable content while shaping discussions (Mangold \& Faulds, 2009; Muñiz \& Schau 2011; Kietzman et al., 2013). Marketing therefore has become increasingly about mediating relationships between different parties and managing multiple social network profiles influencing and directing the agency of others.

\section{Spaces of Storytelling}

When people connect in social media and share content with their virtual friends and acquaintances, they are in essence all storytellers and the sharing of stories is how they 
perform socialities. If a story has sufficient appeal and interest, it can spread beyond people's own networks in social media and potentially be shared around the globe. It can go 'viral'. Hence, if people have the right storytelling competencies, the potential dissemination and reach of stories can result in them influencing millions of people. Thus, great storytelling leads to influence and power; it can affect discourses.

Stories have long provided people with a deeper meaning of life (Fog, Budtz and Yakaboyu, 2005). Humans are seen as "homo narrans" where telling stories are an essential part of their nature (Fisher, 1984, p. 6). Through the exchange of stories, people negotiate and find their role in society (Escalas, 1997). Stories are the foundation of human identity (Gubrium and Holstein, 1998). Stories also provide humans with a mechanism for escape, becoming immersed in the plots, characters and descriptions of the stories (McCabe \& Foster, 2006). Stories thus provide humans with values and teaches them right from wrong, while also delivering entertainment and leisure.

As mentioned, stories affect discourse. Discourse are a group of statements that constructs a topic while discursive formations sustain 'regimes of truths', which are types of discourse regarded by society as true (Foucault, 1980). The mechanisms of social media illustrate Foucault's (1977) ideas about knowledge, power and fluidity: individuals, media, marketers and other parties are circulating stories and contending to influence discourse. Due to the establishment of regimes of truth, certain ways of interpreting the world are privileged, given credibility and status as knowledge, while other information is discarded, subjugated and deemed untrue (Foucault, 1980; Haugaard, 2002). DMOs should try to influence the discourses in social media and try to impose their way of interpreting the world; their regimes of truth.

This paper utilises two terms, stories and narratives, which as Van Laer, De Ruyter, Visconti and Wetzels (2013) point out, need distinguishing. Stories are the storyteller's production; a storyteller's account of an event or a sequence of events. A narrative, on the other hand, is a story the consumer interprets in accordance with his or her prior knowledge, attention, and personality (ibid). Interpretation thus constitutes an act of consumption through which a story is converted into a narrative. However, there are no binary structures as co-creation creates a cycle of multiple agents of production and consumption as these processes become intertwined. 
It is widely accepted among scholars that storytelling is imperative in branding a product (Bierman, 2010; Fog et al., 2005: Herskovitz \& Chrystal, 2010; Jensen, 1999; Mathew \& Wacker, 2007; Wachtman and Johnson, 2009). Stories come with many touch points to the lives of the listeners, facilitating an emotional connection (Woodside, 2010), and communicating brand values (Fog et al., 2005). Without a special story, there is nothing distinctive about brands (Bierman, 2010). Consumers can use brands to enact archetypal myths (Woodside, Sood \& Miller, 2008). Hence, they can identify with the brand persona and become the protagonists of their story. Brands can thus differentiate themselves through authentic stories with interesting characters rooted in the reality of the product (Gunelius, 2013). As proposed in narrative transportation theory, when consumers lose themselves in a story, their attitudes and intentions change to reflect that story, which explains the persuasive effect of stories on consumers (Van Laer et al., 2013). Attractive brand narratives convince consumers to buy products.

Contemporary travel is about consuming and producing narratives; it is about narrative identity and entitlement (Noy, 2012). Narratives of travel are not only an essential ingredient in the construction of personal, collective and place identities, but are also important in the process of contemplating, experiencing, remembering and disseminating travel and tourism experiences (Tivers \& Rakić, 2012). Tourists are co-creators of tourism experiences in which narratives are co-constructed through interaction between the producers and consumers (Chronis, 2012). Hence, narration lies at the very heart of tourism as experiences are essentially co-constructed stories (Bendix, 2002).

Destinations are essentially storyscapes where stories can transform otherwise indifferent spaces into attractive tourist destinations (Chronis, 2005). Stories can make the destination visible and unique (Hsu, Dehuang \& Woodside, 2009). However, rather than identifying the destination as the protagonist in the story, destination marketers can position the destination as an enabler for the visitor to be a protagonist, encountering and overcoming antagonists and achieving particular archetype outcomes (Woodside \& Megehee, 2009). Every great story needs forces of antagonism that the protagonists need to confront in their pursuit of desired objectives (Mckee, 2016). Tourists are thus the central character in a narrative staged by DMOs, and stakeholders and marketers may utilise the story structure of classical folktales in creating, for instance, a dream world in which tourists can become immersed (Mossberg, 2008). Storytelling about a protagonist on a journey can 
therefore be used by DMOs to market the destination as it arouses the audiences' emotions and energy (Woodside \& Megehee, 2009). Ultimately, the success of a narrative presentation in tourism destinations depends on the tourists' involvement, willingness and ability to actively participate in the storytelling experience (Chronis, 2012).

The narratives co-created and consumed at destinations are often mediated through storytelling on social media. DMOs must also actively re-engage with their tourists online to utilise, repackage and spread the positive narratives experienced at the destination. The most engaging and effective social media campaigns engage users in some form of interactive story or game, which create a shared experience between the company and the users (Kaplan, 2012). The co-created narratives by DMOs and tourists are hence an effective way to connect with tourists in an embodied and emotional manner while also reaching their social networks. As many media producers are competing for attention on various social media platforms, the appeal of their stories is vital in attracting consumers who face a plethora of media choices. Emotional and personal storytelling is thus a powerful technology for socialising and creating influence.

Social media are spaces of storytelling as millions of stories representing multiple identities, realities and brands are circulating within them, influencing values and perceptions. Due to these spaces of storytelling, brands are also changing and being renegotiated; they are not demarcated coherent entities. They come in multiple versions and are fluid and part of individuals' bricolages of self-representations. Brands should therefore be seen as a result of embodied performances of storytelling in social circles. They are employed in the construction of social roles and identities.

\section{Technologies of Power}

Influence in social media is a function of reach, which is the degree of the person's embeddedness in the social network, and persuasiveness with regard to the relevance of the content the person creates online (Labrecque et al., 2013). In order for marketers to achieve influence they must utilise what Foucault (1977) termed 'technologies of power'. Technologies of power are techniques used in the practical operation of power, which can be used by individuals and groups in social media to exert influence on others. According to Foucault (1980), power is everywhere; it is not a resource in the hands of a specific group or 
institution. Power is not an entity; it is fluid; it circulates and flows in multiple directions towards interesting and relevant knowledge/stories and the individuals who produce it. The production and circulation of meaning and knowledge is what produces power (Foucault, 1977). It is ingrained in the social network (Cole \& Church, 2007). Social media thus facilitate a democratisation of media production and communication because they afford every user the opportunity to produce power.

Technologies of power enable individuals and their social groups to stimulate engagement and exert influence within their social networks and beyond. They shape the social mechanisms of social media networks and determine social interactions. With the democratisation of content production, users can use their individual storytelling capabilities, their mobilities and their performances and performativities as technologies of power in gaining influence within their social networks. Individuals can express identity, construct social roles, increase status, expand their social networks and influence discourses and consequently brand narratives. Technologies of power therefore centre on the expressions of self and identity of individuals or groups and their associated social practices. There are 'agents' and 'targets' within the power relationship (Cheong \& Miller, 2000). The targets are the subordinate actors in a power relationship while the agents perform their power through the construction and exertion of knowledge and the 'truth'. The agents are also responsible for repression and exclusion. However, there is no binary structure of dominators and dominated as people can possess and dispossess power in different circumstances at different times (ibid). In order to preserve power, DMOs must keep creating and participating in great stories, so they can remain agents. Attracting power through storytelling is thus the main focus of social media branding. If DMOs can influence discourses, they can influence brand narratives.

For DMOs, it is therefore not only about producing exciting stories, but also about becoming an integral part of these politicised online social networks where individuals are socialising, interacting, conversing and sharing stories for mostly non-commercial reasons. They can do that by utilising the technologies of power that are available to individuals in social media. Not only can marketers understand how people act, socialise and influence each other but they can also become agents who penetrate and embed themselves into social networks where they share stories and promote brand narratives. The particular sociological concepts constituting the technologies of power - storytelling, performance, 
performativity, and mobility - thus give leverage in understanding social mechanisms and should therefore move into the centre stage of branding and marketing theory, as DMOs have to understand and utilise the social processes of social media before they can do branding within the context of these social relations. Based on this understanding, a conceptual framework demonstrating the social processes of storytelling within social media is presented.

\section{The Conceptual Framework}

A framework is proposed that draws upon four key sociological concepts which are discussed sequentially here as technologies of power, for the leverage they provide in in the practical operation of power that can be utilised by individuals and groups in social media to exert influence on others. These key concepts are storytelling, mobilities, performances, and performativities. The conceptual framework has two main objectives: first, for researchers, it illustrates the politics and social mechanisms within social media and provides a tool for conducting research into the users' influence on social media branding. Second, the framework provides DMOs with insights on how to strengthen their brands by considering and utilising the technologies of power that users have at their disposal.

\subsection{The centrality of storytelling}

The concept of storytelling has already been introduced above due to its essential role in social media branding. However, it is important to consider its role relative to the other technologies. Storytelling is the most central of the four technologies of power as social media consist of text and images through which users tell stories to communicate their actions and ideas and to produce self-representations. As stories are the means of communication, it underscores the notion of social media as spaces of storytelling. While storytelling is the primary technology, the three other technologies of power - performances, performativities and mobilities - are the secondary technologies, as they are instrumental in increasing the attractiveness of the users' stories (Figure 1). The effective use of these secondary technologies can potentially make users' stories more personal, meaningful and energetic and thus increase their interaction with their social networks. Hence, they contribute to the act of storytelling and create an appealing social role. DMOs must utilise all four technologies of power in order to penetrate online social networks. 


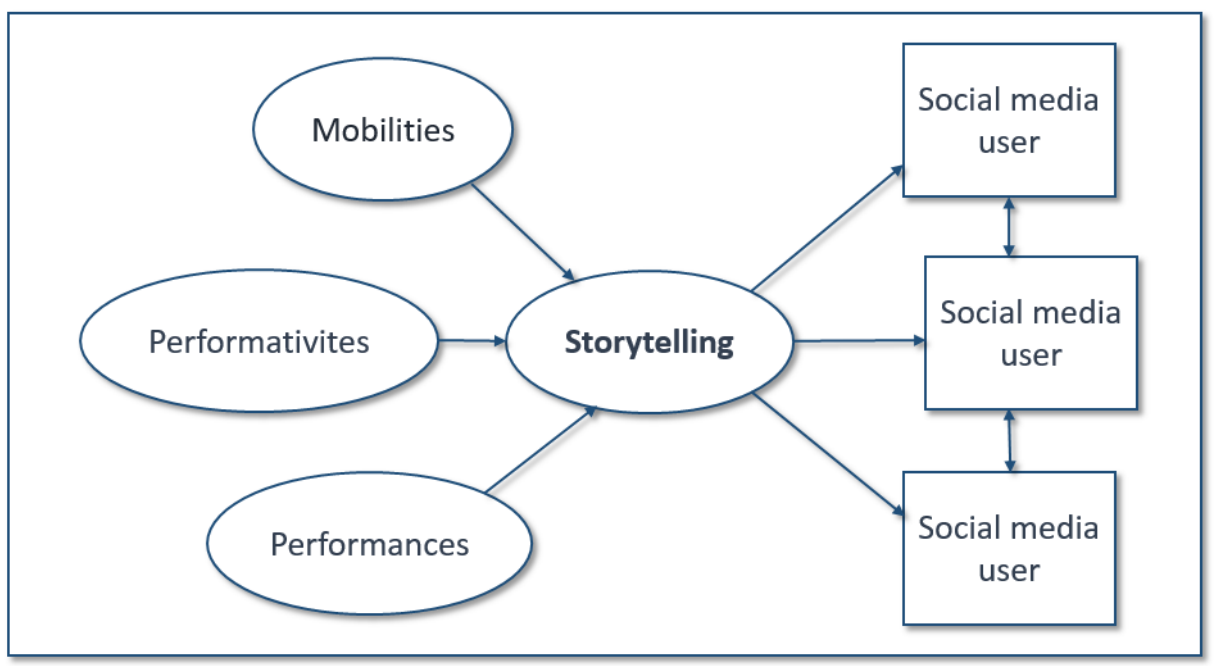

Figure 1. Technologies of power in social media. The storytelling of a user influences other users.

\subsection{Mobilities and reach}

The fluidities of knowledge, power, identities and brand narratives puts mobilities at an important position as a secondary technology of power in the conceptual framework. Mobilities distribute and facilitate the flow of stories. As Peters et al. (2013) point out, social media are living organisms and are therefore in a constant mode of flux as users come, go, and share content among their social networks. The content flows from one user to another and is renegotiated, distorted and fragmented. It is important to view mobilities of information as a limited resource wherein some stories are privileged while others are subjugated, which leads to an unequal distribution of power. If the stories are not liked, commented on or shared, they are not easily mobilised within storytellers' social circles and beyond. This is not an uncommon phenomenon in social media, as only $12 \%$ of Facebook posts reach their friends (Constine, 2012), and 71\% of tweets go unnoticed (Bosker, 2010).

Corporeal mobilities also play a role in the distribution of stories. Research shows that the representation of corporeal mobilities on Facebook are framed positively; users who present themselves as always on the move, as always active, receive admiration from their connections and gain social status (Gössling \& Stavrinidi, 2015). Hence, mobilities increase the likelihood of mediated experiences being shared, and contribute to a greater distribution of knowledge through networks. In the offline world, mobilities give access to travel, education, career opportunities, exploration and new insights while in the online 
world it gives access to social networks, new connections and further knowledge. It is the mediation of these in the fusion of the physical and virtual worlds through which higher status and even greater influence are achieved. Mobilities therefore produce social relations as they enable networking and socialising (Cresswell, 2010). However, socialities also produce mobilities, as storytellers with large social networks have a greater chance of having their stories shared. Mobilities and power therefore generate further access to socialities in social media, which in return generate further access to mobility and thus power.

Although the resource of mobility can to some degree be purchased in social media by for instance paying for Facebook ads, it is essential for marketers to build up their reach in social media by focusing on the mechanisms generated by corporeal mobilities and social reach and try to create memorable stories that accrue them more influence. However, in order to succeed fully in these online social networks, DMOs have to also utilise the last two technologies of power, performance and performativities, in order to generate more personable and relevant stories for social media users.

\subsection{Performance and Performativities}

Performance and performativities are the last two technologies of power in the conceptual framework, and are closely interconnected. It is for this reason that they will be addressed under the same subheading. For DMOs, they are vital in producing personalised stories that engage social media members. With regard to the concept of performance, a range of studies draw on the theories of Goffman (1959), and consider social media as spaces for staging performances and conducting impression management (Grasmuck, Martin \& Zhao, 2009; Krämer \& Winter, 2008; Manago, Graham, Greenfield \& Salimkhan, 2008; Zhao, Grasmuck \& Martin, 2008). Social media are therefore spaces for self-representation where people through consistent and sustained actions and social interactions are able to assume certain social roles and shape an image, which is in line with how they want to be perceived within their network (Kaplan, 2012: Kaplan \& Haenlein, 2010; Peters et al., 2013). Social media users employ popular cultural icons, catch phrases, music, text, images and film clips in collages and these assemblages of different media constitute their self-representation (Williams, 2008; Smith, Fischer \& Chen, 2012). 
Brands are used in this context as a resource to construct and express identities: brands are changed and customised in order to fit user's individual identity projects (Gensler et al., 2013; Smith et al., 2012). Furthermore, as social roles are dynamic concepts, they are continually reshaped through the process of social interactions and communication within socialities (Peters et al., 2013), and brand narratives may therefore be changed in line with changing roles. Brands are thus absorbed into individuals' self-representations, where they are modified and personalised to construct desired social roles and then mediated through improvised performances to audiences within the social network. This affects the way brands are interpreted and perceived on social media. If users are delivering competent performances in their acts of storytelling, they are, consciously or not, utilising their performances as a technology of power. It means that engaging in enjoyable performances of storytelling attract audiences and through the connection made with them, storytellers can impose their values and worldview on them. Crucially, storytellers also impose their interpretation and customisation of the brand narrative on audiences. Ultimately, brands are reliant on how these individual performances are staged and DMOs have to interact with these performing storytellers and affect their interpretations of the brand while finding ways to create their own performances. Thus, brands and brand identities are co-created in an active negotiation of organisational and consumer identities.

While performances are self-representations and construct social roles, the performative does things: it constructs meaning and constitutes reality through individual's social interactions (Cohen \& Cohen, 2012; Harwood \& El-Manstrly, 2012). The mediated experiences of storytellers become performative when they create subjective and alternative versions of reality that potentially change perceptions. Adopting the ideas of Butler (1993), online social networks can be seen as frameworks of performativity in the sense that the self is discursively produced by the given norms and categories established by the social media site (Cover, 2012; Van House, 2011). Values and practices of other social network members also influence people's performances. Storytellers are therefore not entirely independent agents as the performative can signify the function of social structures, practices and discourses in constituting identities and constructing performances. However, strong performances of storytelling by individuals can construct meaning, resist dominant discourses and change narratives in their custody. 
Performativities may be the least demonstrable technology of power, as they are concerned with the construction of spaces, meanings and realities and consider how social structures, practices and discourses constitute identities. However, performativity's role in influencing discourses, the regimes of truth and consequently brand narratives is vital. Without recognising the powers of performativity to influence discourse, DMOs will find it difficult to influence brand narratives in social media. Ultimately, it is essential that marketers acknowledge and deploy performances and performativity as technologies of power, as these can shape social interactions, perceptions and discourses in social networks and therefore also brand narratives.

In summary, storytelling, mobilities, performance, and performativity are crucial concepts that further understanding of the social mechanisms of social media and their implications for brand management. Memorable entertaining stories can break down barriers to social networks and invite marketers in; they are the vitals vessels through which to reach audiences and influence narratives. How, by whom and through which conduits these stories are told are, however, equally important. Without personal passionate performances, without social connections and without the right distribution channels, stories will fail to gain traction. Brand narratives draw from an amalgam of storytellers' mobilities, performances and performativities, enabling multiple constructed realities and discourses that are dynamic and changing in fluid social networks. As marketers, DMOs must learn how to manoeuvre in these complex politicised social spaces utilising the technologies of power social media place at their disposal. The conceptual framework developed here shows how the individuals' identities and social interactions play a key role in the co-created brand.

\section{The case of VisitDenmark}

This paper is primarily conceptual with a focus on presenting the framework's technologies of power and their role in destination branding. However, a brief practical example from VisitDenmark's social media branding practices is provided to illustrate the usefulness of the conceptual framework. VisitDenmark is the national DMO of Denmark and it is appointed by the Danish Government to market the country internationally to tourists and business travellers (VisitDenmark, 2015). According to VisitDenmark, they have a large impact on tourism receipts to Denmark. For instance, over 800,000 people visited Denmark in 2014 due to their marketing and branding efforts (VisitDenmark, 2014a). A large share of their 
marketing takes place via digital media where VisitDenmark are active on all the major social media platforms. Their social media strategy recognises the active co-creative role of consumers in marketing and branding (VisitDenmark, 2014b). Specifically, the DMO is focused on Facebook where on a daily basis they publish posts and frequently create campaigns in cooperation with tourism stakeholders and social media users (Go VisitDenmark, 2017). The practical example that follows, which is based on a case study approach with netnography as its central method, is from Facebook and illustrates how VisitDenmark uses tourists' social media content to create branding campaigns for Denmark.

\subsection{Case study approach}

A case study examines a phenomenon within a real-life context (Guest, Namey \& Mitchel, 2013). Its purpose is to develop an in-depth understanding of what is happening and why it is happening at a specific point of time in a specific context (Garrod \& Fyall, 2011). Case studies are characterised by an intensive analysis of a specific individual unit (Flybjerg, 2011), which will provide a clearer picture of what is going on in the broader context (Garrod \& Fyall, 2011). They are especially applicable in exploratory research where a new phenomenon is studied (Veal, 2006). The aim for this brief case study of VisitDenmark is to explore and understand the phenomenon of how DMOs use the relatively new marketing channel of social media to co-create the brand narrative of a destination by utilising the storytelling and mediated experiences of social media users.

As VisitDenmark is very active on social media, one case study is deemed sufficient for the enquiry into a new phenomenon. It provides an insightful case to learn wider lessons about how to use social media for co-created branding campaigns. The study of VisitDenmark is thus an instrumental case study (Garrod \& Fyall, 2011).

\subsection{Netnography}

The central method for the case study is netnography, as the analysis of social media users' stories calls for a qualitative approach. Netnography (Kozinets, 2010), also called a virtual ethnography (Hine, 2000), is employed as an appropriate data collection technique to understand their online social behaviour. Netnography is participant-observational research based on online fieldwork (Kozinets, 2010). As with offline ethnography, it facilitates the opportunity to investigate newly identified social issues or behaviours (LeCompte \& 
Schensul, 2010). A netnography in social media provides an opportunity to understand peoples' everyday social behaviour as social media increasingly become part of human nature (Kozinets, 2015). Netnography facilitates the research of peoples' concerns, needs, feelings and ideas as they exchange life narratives choosing from a range of identities (ibid). A netnography is thus appropriate for this inquiry which examines the social behaviour in which people utilise technologies of power to share stories, perform identity and influence perceptions and narratives as part of increasing their influence in social networks.

The netnography of this paper's case study focuses on Facebook posts by VisitDenmark that are co-created with social media users who provide stories and images. Specifically it concentrates on a particular example, a post from one of VisitDenmark's Ambassador Albums. Social media users are asked to contribute their photos to an Ambassador Album and write stories about their experiences which accompany each photo. A total of 25 posts published by VisitDenmark, between July 2014 and December 2015, were sampled and their content subjected to discourse analysis. The focus on the performative and power dimensions in storytelling justifies the use of discourse analysis to interpret the data. Discourse analysis is the study of language use and its role in social life and in constructing the world (Potter, 2008). It views language as constructive and constructed (Gill, 2000; Phillips \& Hardy, 2002). In other words, texts are the product of reality while also producing discursive-based understandings of aspects of reality (Cheek, 2008). Peoples' storytelling constructs identities and realities and therefore also destination brands.

\subsection{VisitDenmark}

VisitDenmark has a strong interest in sourcing user generated content (UGC) for their social media activities as they recognise that people's recommendations and shared experiences influence consumers' perceptions and decision-making process (VisitDenmark, 2014b). One of the ways that they source UGC is through Instagram where users share photos with VisitDenmark's account. If VisitDenmark spots interesting photos, they will use them for their Ambassador Albums on Facebook. The procedure is that they ask the Instagrammers for permission to use the photos while encouraging them to write a story to supplement them. According to Sylvest Jensen (personal communication, October 7, 2015), head of 
Digital Media at VisitDenmark, the tourists nearly always agree to have their photos published, as they feel proud to be selected.

In a conversation with Sylvest Jensen (personal communication, October 7, 2015), a specific Ambassador Album (Figure 2) by an Instagrammer was mentioned as an example of one of the most engaging stories they had posted on Facebook (Go VisitDenmark, 2015, 10 September). The album was successful as the author of the story had given a personal account of his experience on the Danish island of Røm $\varnothing$ and there were many comments from people who reminisced about their own trip to the island (Sylvest Jensen, personal communication, October 7,2015$)$. The album reached more than 45,000 people and had 90 comments and 255 shares (Figure 2). As the album was held up as an example of good storytelling, it is worth examining for its application of technologies of power in order to assess the usefulness of the conceptual framework.

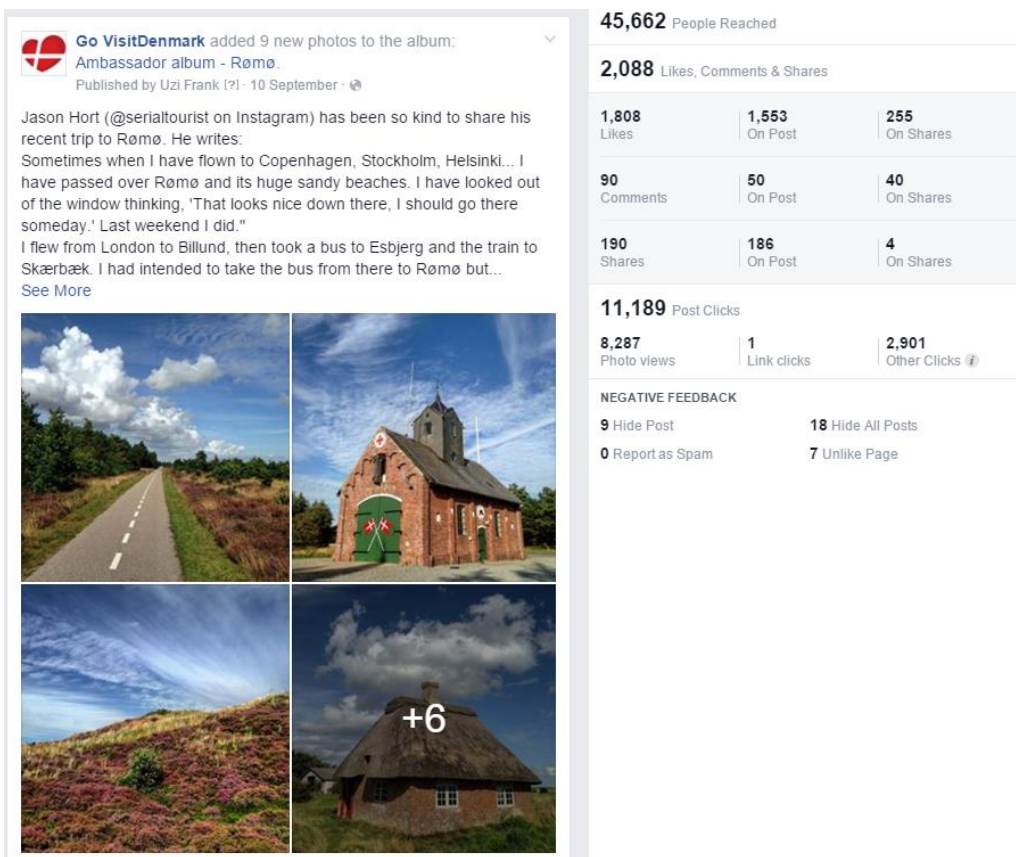

Figure 2. Ambassador Album by Jason Hort and his trip to Rømø (Go VisitDenmark, 2015, 10 September).

It can be argued that that the success of Jason Hort's posts in this album is owing to VisitDenmark inadvertently utilising all four technologies of power of the conceptual framework. First, they utilise Hort's corporeal mobility as he has travelled in Denmark. VisitDenmark also utilises his online mobility capital as he has 931 followers on Instagram (Serialtourist, 2015) in addition to his social network on Facebook. Second, VisitDenmark provides Hort with a stage to act on, where he can put on a performance and establish a 
social role, and he utilises it. He puts on a strong storytelling performance where he writes a long text about the trip around the island, providing a humorous tale about how he cycles around the island meeting friendly people and engages in various interesting activities. He utilises the island to establish himself as an adventurer, explorer and competent observer. The destination therefore becomes part of his social role and self-representation, whilst simultaneously, his performance and social role reflects how the destination is perceived and has been consumed. He becomes a protagonist that users can identify with so they can imagine their own trip to Røm $\varnothing$. Users begin to come to understand a destination through his subjective interpretation of place; his personal story provides the brand with a personality. Third, his performance is performative as he frames the island as a cycling destination with room for everyone. Reading the comment section, the storytelling performance of Hort has a strong influence on VisitDenmark's followers: some are reminded of their trip to the island and reiterate the positive story of the island, while others are looking forward to their forthcoming trip and feel the story shows they have made the right choice (Go VisitDenmark, 2015, 10 September). Hence, the story appeals to loyal visitors as well as potential new visitors. VisitDenmark and Hort are two agents joining forces to create a fleeting alliance that draws in power and serves their own interests. Hort achieves status and recognition while VisitDenmark acquires a credible source to promote their destination. Together they co-create the brand of Rømø. The example illustrates how DMOs can be successful in promoting the brand narrative by engaging with consumers through the technologies of power.

\section{Implication for DMOs}

The conceptual framework developed in this paper has significant implications for how DMOs understand social media and how they approach their branding strategy. Utilising the technologies of power provides DMOs with practical tools for reaching and influencing consumers in social media. Five recommendations for strengthening branding practices in social media are offered based on the conceptual framework and the role of technologies of power:

1) DMOs have to break the barrier between the online and offline world so as to merge virtual and physical mobilities. Users have to feel that there is a real impact when 
they like, comment on or share a post, with an impact either on their own lives or on others'. This can for example be through a campaign where users' virtual actions affect the appearance or character of a product, place or person and they can play a part in developing the campaign further, taking ownership of its course. This creates a personal connection between users and marketers where users feel acknowledged and influential. These campaigns are strongly performative in the sense that communications change things; it empowers the users and engages them.

2) DMOs have to recognise the importance of collaborative storytelling with a range of storytellers in social networks. DMOs and users are telling stories and creating narratives; both are giving and taking and mutually moulding the brand through improvised and strategic performances. DMOs have to be proactive as well as reactive. They have to sit back and let unpredictable conversations run, sometimes stepping in to fuel the dialogue, while energising the communicative mobilities and creating reach and influence. As curators, they must pick and choose the stories that benefit their preferred narrative and involve the users in these evolving storylines. For example, photos, videos and descriptions of users feed into the brand narratives and strengthen the products' appeal, as its personality is the consequence of amalgamated co-created accounts.

3) DMOs have to be constantly active in daily conversations, listening and maintaining dialogue, continually co-creating stories with the users. Power is fluid and flowing towards influential and active storytellers. When DMOs have created an emotional and personal connections with users, they need to maintain relations. If users feel they are not part of the conversations, social relations will cease and influence will fade away. Hence, DMOs must keep creating great stories to retain their power and thus their ability to impose their regimes of truth. For smaller DMOs the continued co-creation of stories will be a challenge, as they lack the resources to maintain a dialogue with high volumes of social media users. The answer is to concentrate exclusively on influential users with large social networks or to focus on the most engaging stories that can facilitate reach and goodwill.

4) DMOs have to think of social media users as potential allies with whom they have a common agenda. The users can be motivated to engage if they feel that they can gain something, such as status, appreciation or support. For instance, Instagram users who 
share various images of their experiences with a certain product or place can be swayed to contribute to a campaign if they are given the opportunity to promote themselves, stage spaces of self-representation, mobilising and expanding their network and influence. DMOs also benefit as they acquire a credible source to promote their products and utilise the user's social networks and influence. The user and DMO are storytelling agents joining forces to create a brief alliance that draws in power. However, there will be times when users are antagonists who spread negative narratives as part of an opposing agenda. Most of these narratives can be ignored. They quickly fade away in the fluidities of social media spaces if they are not replenished by new contributions. Only if negative narratives are continually flourishing due to persistent inputs or powerful users, should DMOs try to enter in dialogue with the users and demonstrate interest in order to pause or halt their storytelling activities.

5) DMOs have to think as individual storytellers and consider how they would perform their social role and mediate their experiences in a social network. Marketing and branding has become individualised as well as collective. DMOs need to consider how they stage strategic sustained performances through mediated emotional and personal experiences, enabling them to assume a certain social role with which users can identify. The creation of personal emotional bonds enable trust and commitment, generating ambassadors and allies advocating the brand narratives. For instance, an on-going sequential story acted out by an individual personifying the brand narrative can create spaces of rapport and engagement.

The underlying lesson from these recommendations is that DMOs should consider the four technologies of power each time they plan a campaign, publish a post or engage in conversations. DMOs must ask themselves if the stories they share have an exciting protagonist with whom users can identify, who stage enjoyable active performances as part of their social roles. These stories have to do and change something, creating performative spaces physically and virtually, which generate virtual and communicative mobilities and thus reach - the fundamental antecedent for power. 


\section{Contribution, Limitations and Future Research}

This paper provides a number of key contributions to existing research. First, it argued that particular concepts from the sphere of sociology must to be moved to the centre stage of branding strategies, as DMOs need to understand the social mechanisms of social media in order to successfully brand their products. Second, social media are characterised as spaces of storytelling where power is ingrained in the social network flowing towards the active storytellers. DMOs are therefore given a new understanding of the essence of social media, which can enable them to modify their strategies. Third, a conceptual framework was proposed drawing on four sociological technologies of power: storytelling, mobilities, performances and performativities, jointly illustrating the politics and social processes within social media. The framework can be termed an 'identifying' conceptualisation (Maclnnis, 2011), as it provides a new approach to interpreting online social networks and social media branding, and it proposes a theory on how DMOs can adapt their branding practices to this new social environment. The framework offers a theoretical basis to conduct future empirical research into how individuals' identities and social interactions play a key role in the co-created brand. Fourth, the introduction of technologies of power in social media, where politics and social mechanisms decide the success of stories, provides DMOs with a novel perspective on why some stories are energised and spread through social networks while others fail to gain traction. Fifth, the conceptual framework offers a basis for innovative social media practices, as it presents a way for DMOs to navigate within socialities and utilise the instruments they have at their disposal to energise and mobilise stories and thus promote their agenda. Finally, based on the framework, five distinct practical recommendations for branding practices in social media were presented.

This paper is conceptually weighted, presenting only a brief empirical case study to substantiate its conceptual framework. The present work therefore sets a basis for future dedicated empirical work. It has several limitations that also provide directions for future research. First, as most commercial sectors are becoming more reliant on social media for branding and marketing, future research should investigate the application of the conceptual framework in the context of other sectors to examine the potential differences due to particular business environments. Second, this paper does not consider other variables such as the changing algorithms of social media platforms. For instance, algorithms at Facebook have changed over the last few years, privileging paid reach while 
disadvantaging earned reach. Further research should explore the continued potential of applying the technologies of power to activate earned reach in the context of these changing algorithms. Third, this paper only focuses on 'normal users', and does not consider other storytelling agents within social media such as industry stakeholders, professional bloggers or media organisations. These storytelling agents would generally be more powerful than 'normal users' due to their number of followers, their access to paid media and their ample resources in terms of seeding content and maintaining dialogue. Their activities could affect perceptions of the veracity of some narratives and therefore the effectiveness of aspects of the recommendations. However, the primary rationale behind the conceptual framework and its technologies of power is to generate appealing stories and organic reach in collaboration with 'normal users', and thus utilise a largely untapped potential in social media branding. Future research could incorporate these other agents into the conceptual framework to explore the opportunities they bring with regard to utilising the technologies of power.

\section{References}

Adams, P. (2012). Grouped: How small groups of friends are the key to influence on the social web. California: New Riders.

Anderson S. Hamilton K. \& Tonner A. (2016). Social Labour: Exploring work in consumption. Marketing theory, 16(3), $383-400$.

Barnes, K. L. (2015). The Big Reveal: Budgets, Staffing and the Future of Social Media at DMOs. www.destinationmarketing.org/blog/big-reveal-budgets-staffing-and-futuresocial-media-dmos Accessed 18.03.17

Bendix, R. (2002). Capitalizing on memories past, present, and future: Observations on the intertwining of tourism and narration. Anthropological theory, 2 (4), 469-87.

Bertino, M. (2014). New research: Topics that get a reaction. Retrieved March 17, 2017, from http://kloutblog.lithium.com/t5/Klout-Blog/New-Research-Topics-That-Get-AReaction/ba-p/578

Berthon, P. R., Pitt, L. F., Plangger, K., \& Shapiro, D. (2012). Marketing Meets Web 2.0, Social Media, and Creative Consumers: Implications for International Marketing Strategy. Business Horizons, 55(3), 261-71.

Bierman, J. (2010). Tell me a story. NZ Business, 24(10), 40-41. 
Bosker, B. (2010). 71 percent of Tweets Are Ignored, Study Finds. Huffington Post. from http://www.huffingtonpost.com/2010/10/12/71-percent-of-tweets-are_n_759176.html Accessed 17.03.17.

Buhalis, D. \& Foerste, M. (2015). SoCoMo marketing for travel and tourism: Empowering cocreation of value. Journal of Destination Marketing \& Management, 4, 151-161.

Butler, J. (1993) Bodies That Matter: On the Discursive Limits of Sex. New York: Routledge.

Cheek, J. (2008). Foucauldian discourse analysis. In L. M. Given (Ed.). The SAGE encyclopaedia of qualitative research methods (pp. 355-357). Thousand Oaks: Sage Publications Inc.

Cheong, S. M, \& Miller, M. L. (2000). Power and tourism: A foucauldian Observation. Annals of Tourism Research, 27(2), 371- 390.

Chronis, A. (2005). Coconstructing Heritage at the Gettysburg Storyscape. Annals of Tourism Research, 32 (2), 386-406.

Chronis, A. (2012). Tourists as Story-Builders: Narrative Construction at a Heritage Museum. Journal of Travel \& Tourism Marketing, 29 (5), 444-459.

Cohen, E. \& Cohen, S. A. (2012). Current sociological theories and issues in tourism. Annals of Tourism Research, 39(4), 2177-2202.

Cole, T. \& Church, A. (2007). Tourism, politics and the forgotten entanglements of power. In A. Church, \& T. Cole (eds.), Tourism, Power and Space (1-42). UK: Routledge.

Constine, J. (2012). Your average Facebook Post Only Reaches 12\% Of Your Friends. http://techcrunch.com/2012/02/29/facebook-post-reach-16-friends/ Accessed 17.03.17.

Cover, R. (2012). Performing and undoing identity online: Social networking, identity theories and the incompatibility of online profiles and friendship regimes. Convergence: The international Journal of research into New Media Technologies, 18(2), 177-193.

Crang, M. \& Cook, I. (2007). Doing Ethnographies. Sage Publications Ltd.

Cresswell, T. (2010). Towards a politics of mobility. Environment and planning D: Society and space, $28,17-31$.

DesAutels, P. (2011). UGIS: Understanding the nature of user-generated information systems. Business Horizons, 54(3), 185-92.

Digital tourism Think Tank (2013). The European NTO Digital Benchmark. Retrieved May 23, 2015, from http://thinkdigital.travel/reports/The_European_NTO_Digital_Benchmark.pdf

Escalas, J. E. (1997). The positive effects of narrative thought in response to advertising. Advances in Consumer Research, 24, 67-68. 
Fisher, W. R. (1984). Narration as a human communication paradigm: The case of public argument. Communication Monographs, 51, 1-22.

Fisher D. \& Smith S. (2011). Cocreation is chaotic: What it means for marketing when no one has control. Marketing theory, 11(3), $325-350$.

Flyvbjerg, B. (2011). Case study, In N. K. Denzin, N. K. \& Y. S. Lincoln (eds.). The sage handbook of qualitative research (pp. 301-316). Thousand Oaks: Sage Publications Inc.

Fog, K., Budtz, C., \& Yakaboylu, B. (2005). Storytelling: Branding in practice. Germany: Springer.

Foucault, M. (1977). Discipline and Punish: The Birth of the Prison. London: Allen Lane, Penguin.

Foucault, M. (1980). Power/Knowledge: Selected interviews and Other writings, 1972-1977. New York: Pantheon Books.

Fournier, S. \& Avery, J. (2011). The Uninvited Brand, Business Horizons, 54(3), 193-207.

Garrod, B. \& Fyall, A. (2011). The case study approach: wrongly maligned. In B. Garrod, B. \& A. Fyall (eds.) Contemporary cases in tourism (pp. IX-XVI). Oxford: Goodfellow Publishers.

Gensler, S., Völckner, F. Liu-Thompkins, Y., \& Wiertz, C. (2013). Managing Brands in the Social Media Environment. Journal of Interactive Marketing, 27(4), 242-56.

Gill, R. (2000). Discourse Analysis. In M. W. Bauer \& G. Gaskell (eds.). Qualitative researching with text, image and sound: A practical handbook (pp. 172-190). London: Sage Publications Ltd.

Go VisitDenmark (2015, 10 September). Ambassador Album - Rømø (Facebook post). Retrieved October 15, 2015, from https://www.facebook.com/denmark?fref=ts

Go VisitDenmark (2017). In Facebook (Company page). Retrieved March 15, 2017, from https://www.facebook.com/denmark/?fref=ts

Goffman, E. (1959). The presentation of Self in everyday life. USA: Anchor Books.

Gössling, S. \& Stavrinidi, I. (2015). Social networking, mobilities, and the rise of liquid identities. Mobilities, DOI: 10.1080/17450101.2015.1034453.

Grasmuck, S., Martin, J., \& Zhao, S. (2009). Ethno-racial identity displays on Facebook. Journal of Computer Mediated Communication, 15(1), 158-188.

Gubrium, J. F. \& Holstein, J. A. (1998). Narrative Practice and the Coherence of Personal Stories. The Sociological Quarterly, 39, (1), 163-187. 
Guest, G., Namey, E. E. \& Mitchel, M. L. (2013). Collecting qualitative data: A field manual for applied research. Thousand Oaks: Sage Publications, Inc.

Gunelius, S. (2013). 5 Secrets to Use Storytelling for Brand Marketing Success. https://www.forbes.com/sites/work-in-progress/2013/02/05/5-secrets-to-usingstorytelling-for-brand-marketing-success/\#2e6f1a6b7d81 Accessed 14.03.17.

Hanna, R., Rohm, A., \& Crittenden, V. L. (2011). We're All Connected: The Power of the Social Media Ecosystem. Business Horizons, 54(3), 265-73.

Harwood, S. \& El-Manstrly, D. (2012). The performativity turn in tourism. University of Edinburgh Business School Working Paper Series, 12(5), 1 - 18.

Hays, S., Page, S. J. \& Buhalis, D. (2013). Social media as a destination marketing tool: its use by national tourism organisations. Current issues in tourism, 16 (3), 211-239.

Haugaard, M. (2002). Power: A reader. UK: Manchester University Press.

Herskovitz, S. \& Crystal, M. (2010). The essential brand persona: storytelling and branding. Journal of Business Strategy, 31(3), 21-28.

Hine, C. (2000). Virtual ethnography. London: Sage publications Itd.

Hsu, S., Dehuang, N., \& Woodside, A. G. (2009). Storytelling research of consumers' selfreports of urban tourism experiences in China. Journal Of Business Research, 62, 12231254.

Jensen, R. (1999). Dream Society: How the coming shift from information to imagination will transform your business. New York: McGraw-Hill.

Kaplan, A. M. (2012). If You Love Something, Let It Go Mobile: Mobile Marketing and Mobile Social Media 4x4. Business Horizons, 55(2), 129-39.

Kaplan, A. M. \& Haenlein, M. (2010). Users of the World, Unite! The Challenges and Opportunities of Social Media. Business Horizons, 53(1), 59-68.

Kietzmann, J. H., Hermkens, K., McCarthy, I. P., \& Silvestre, B. S. (2011). Social Media? Get Serious! Understanding the Functional Building Blocks of Social Media. Business Horizons, 54(3), 241-51.

Kladou, S. \& Mavragani, E. (2015). Assessing destination image: an online marketing approach and the case of Tripadvisor. Journal of Destination Marketing \& Management, 4, 187-93.

Kohli, C., Suri, R. \& Kapoor, A. (2015). Will Social Media Kill Branding? Business Horizons, 58(1), 35-44.

Kozinets, R. V. (2010). Netnography: Doing Ethnographic Research Online. Sage Publications, London. 
Kozinets, R. V. (2015). Netnography: Redefined. London: Sage.

Krämer, N. C. \& Winter, S. (2008). Impression management 2.0, the relationship of selfesteem, extraversion, self-efficacy, and self-presentation within social networking sites. Journal of Media Psychology 20(3), 106-116.

Labrecque, L. I. (2014). Fostering Consumer-Brand Relationships in Social Media Environments: The Role of Parasocial Interaction. Chicago Interactive Marketing Association, 28(2), 134-48.

Labrecque, L. I., Esche, J. V. D., Mathwick, C., Novak, T. P., \& Hofacker, C. F. (2013). Consumer Power: Evolution in the Digital Age. Journal of Interactive Marketing, 27, $257-269$.

LeCompte, M. D. \& Schensul, J. J. (2010). Designing and conducting ethnographic research. UK: AltaMira Press.

Leask, A., Fyall, A. \& Barron, P. (2014). Generation Y: An Agenda for Future Visitor Attraction Research. International Journal of Tourism Research, 16, 462-471.

Lo, I. S., Mckercher, B., Lo, A., Cheung, C. \& Law, R. (2011). Tourism and online photography. Tourism Management, 32, 725-731.

Manago, A., Michael, M., Graham, B., Greenfield, P. M., \& Salimkhan, G. (2008). Selfpresentation and gender on Myspace. Journal of Applied Development Psychology, 29, $446-458$

Mangold, W. G. \& Faulds, D. J. (2009). Social Media: The New Hybrid Element of the Promotion Mix. Business Horizons, 52(4), 357-65.

MacInnis, D. J. (2011). A Framework for Conceptual Contributions in Marketing. Journal of Marketing, 75, 136-154.

Martin, D., Woodside, A. G., \& Dehuang, N. (2007). Etic Interpreting of Naïve Subjective Personal Introspections of Tourism Behavior: Analyzing Visitors' Stories about Experiencing Mumbai, Seoul, Singapore, and Tokyo. International Journal of Culture, Tourism, \& Hospitality Research, 1(1), 14-44.

McCabe, S., \& Foster, C. (2006). The role and function of narrative in tourist interaction, Journal of tourism and cultural change, 4 (3), 194-215.

Mckee, R. (2016). Dialogue: The Art of Verbal Action for Page, Stage, and Screen. New York: Twelve.

Mathews, R. \& Wacker, W. (2008). What's your story? Storytelling to move markets, audiences, people, and brands. USA: Pearson Education Inc. 
Morgan, N., \& Pritchard, A. (2004). Meeting the destination branding challenge", In N. Morgan, A. Pritchard \& R. Pride (Eds.) Destination Branding, Creating the unique destination proposition. Oxford: Elsevier Butterworth-Heinemann.

Morgan, N., Pritchard, A. \& Pride, R. (2011). Tourism places, brand and reputation management. In N. Morgan, A. Pritchard \& R. Pride (Eds.) Destination brands: Managing Place reputation $(3-19)$. ( $3^{\text {rd }}$ ed.). Oxford: Butterworth-Heinemann.

Morrison, A. M. (2013). Marketing and managing tourism destinations. New York: Routledge.

Mossberg, L. (2008). Extraordinary Experiences through Storytelling. Scandinavian Journal of Hospitality and Tourism, 8 (3), 195-210.

Muñiz, A. M. \& Schau, H. J. (2011). How to Inspire Value-Laden Collaborative ConsumerGenerated Content. Business Horizons, 54(3), 209-17.

Noy, C. (2012). Narratives and counter-narratives: Contesting a tourist site in Jerusalem, In J. Tivers \& T. Rakić (eds.), Narratives of Travel and Tourism (pp. 135-150). England: Ashgate publishing limited.

Peters, K., Chen, Y., Kaplan, A. M. Ognibeni, B., \& Pauwels, K. (2013). Social Media Metrics A Framework and Guidelines for Managing Social Media. Journal of Interactive Marketing, 27(4), 281-98.

Pike, S. (2004). Destination Marketing Organisations. London: Taylor and Francis.

Potter, J. (2008). Discourse analysis. In L. M. Given (ed.). The Sage encyclopaedia of qualitative research methods (pp. 217-220). Thousand Oaks: Sage Publications Itd.

Phillips, N. \& Hardy, C. (2002). Discourse Analysis. Thousand Oaks: Sage Publications, Inc.

Serialtourist (@serialtourist) (2015). Jason Hort Kent, UK. I like travelling, I do it a lot, I take a few photos along the way. All photos here are mine. tv_travel, tv_pano \& worldplaces member (Instagram). Retrieved October 27, 2015, from https://instagram.com/serialtourist/

Singh, S. \& Sonnenburg, S. (2012). Brand performances in social media. Journal of Interactive Marketing, 26 (4), 189-97.

Smith, A. N., Fischer, E. \& Chen, Y.(2012). How Does Brand-Related User-Generated Content Differ across YouTube, Facebook, and Twitter? Journal of Interactive Marketing, 26 (2), 102-113.

Tiago, M. T. P. M. B. \& Veríssimo, J. M. C. (2014). Digital Marketing and Social Media: Why Bother?. Business Horizons, 57(6), 703-08.

Tivers, J. \& Rakić, T. (2012). Introducing the narratives of travel and tourism. In J. Tivers \& T. 
Rakić (eds.), Narratives of Travel and Tourism (pp. 1-8). England: Ashgate publishing limited.

Van House, N. A. (2011). Feminist HCl meets Facebook: Performativity and social networking sites. Interacting with Computers, 23(5), 422-29.

Van Laer, T., Ruyter, K. D., Visconti, L. M., \& Wetzels, M. (2013). The Extended Transportation-Imagery Model: A Meta-Analysis of the Antecedents and Consequences of Consumers' Narrative Transportation. Journal of Consumer Research, 40, 797-817.

Veal, A. J. (2006.). Research methods for leisure and tourism: a practical guide. England: Pearson Education Itd.

VisitDenmark (2014a). Resultat og retning 2014 - 2015. Retrieved October 13, 2015, from http://www.e-pages.dk/visitdenmark/792/7

VisitDenmark (2014b). Turistens Digitale Rejse. Retrieved October 13, 2015, from http://www.visitdenmark.dk/da/danmark/turistens-digitale-rejse

Visitdenmark (2015). Historien om VisitDenmark. http://www.visitdenmark.dk/da/danmark/historien-om-visitdenmark Accessed 13.10.2015.

Wachtman, E. \& Johnson, S. (2009). The persuasive power of story. Marketing Management, $18(1), 28-34$.

Wang, X., Yu, C., \& Wei, Y. (2012). Social Media Peer Communication and Impacts on Purchase Intentions: A Consumer Socialization Framework. Journal of Interactive Marketing, 26(4), 198-208.

Williams, B. (2008). "What South Park character are you?": Popular culture, literacy, and online performances of identity. Computers and Composition, 25(1), 24-39.

Woodside, A. G. (2010). Brand-Consumer Storytelling Theory and Research: Introduction to a Psychology \& Marketing Special Issue. Psychology \& Marketing, 27 (6), 531-540.

Woodside, A. G., Sood, S. \& Miller, K. E. (2008). When consumers and brands talk: Storytelling theory and research in psychology and marketing. Psychology \& Marketing, $25(2), 97-145$.

Woodside, A. G., Cruickshank, B. F., \& Dehuang, N. (2007). Stories visitors tell about Italian cities as destination icons. Tourism Management, 28 (1), 162-174.

Woodside, Arch G. \& Megehee, C. M. (2009). Travel Storytelling Theory and Practice. Anatolia, 20 (1), 86-99. 
Zhao, S., Grasmuck, S. \& Martin, J. (2008). Identity construction on Facebook: Digital empowerment in anchored relationships. Computers in Human Behavior, 24(5), 181636. 